\title{
DETERMINAN PEMILIHAN MODA TRANSPORTASI PEKERJA KOMUTER JABODETABEK DENGAN MODEL REGRESI LOGISTIK MULTINOMIAL MULTILEVEL*
}

\author{
Hernanto Adwiluvito
}

\author{
Badan Pusat Statistik, Indonesia, adwiluvito@bps.go.id \\ Indonesian Journal of Statistics and Its Applications (elSSN:2599-0802) \\ Vol 3 No 1 (2019), 49 - 61 \\ Copyright $@ 2019$ Hernanto Adwiluvito. This is an open-access article distributed under the Creative \\ Commons Attribution License, which permits unrestricted use, distribution, and reproduction in any
} medium, provided the original work is properly cited.

\begin{abstract}
The BPS noted that commuters in Jabodetabek had increased by 400 thousand people from 2001 to 2014 . The BPS also recorded that around $81,3 \%$ of the commuters in Jabodetabek were workers. A growing number of commuter workers in Jabodetabek makes transportation is very important to support the connection of suburban area and workplace in Jakarta. The result showed that $73 \%$ of the commuter workers used private transportation, $19 \%$ used ground public transportation and the rest of commuter workers used train. This research use Jabodetabek Commuter Survey 2014 as the main source data to shed light on how socioeconomic factors and spatial attributes affect the selection of a primary mode of transportation for commuter workers. Using multilevel multinomial logistic regression, the result confirm that the age, sex, marital status, ownership of vehicle, travel distance and time have a significant effect in explaining train choice. Furthermore, the result also showed that the age, sex, marital status, income, ownership of vehicle, travel distance and cost are found to be significant in explaining ground public transportation choice.
\end{abstract}

Keywords: bayesian, commuter, modal choice, multilevel, multinomial logit.

\section{Pendahuluan}

Selama lebih dari tiga dekade terakhir, terjadi proses suburbanisasi dengan perkembangan wilayah sekitar Jakarta sebagai dampak dari penduduk Jakarta yang cenderung mencari permukiman yang lebih terjangkau di pinggiran kota Jakarta. Perpindahan tempat tinggal ke wilayah suburban Jakarta tidak diikuti oleh perubahan

\footnotetext{
* Received Nov 2018; Accepted Des 2018; Published online on Feb 2019
} 
tempat kegiatan utama penduduknya. Penduduk yang pindah ke wilayah suburban ternyata tetap melakukan kegiatan utama di Jakarta (Ariana, 2004).

BPS (2014) mendefinisikan komuter sebagai seseorang yang melakukan suatu kegiatan bekerja/sekolah/kursus di luar kabupaten/kota tempat tinggal dan secara rutin pergi dan pulang (PP) ke tempat tinggalnya pada hari yang sama. Selanjutnya, seseorang yang melakukan perjalanan rutin dengan tujuan bekerja, pergi dan pulang setiap hari antara tempat tinggal dan tempat bekerja yang berbeda kabupaten/kota disebut sebagai pekerja komuter (BPS, 2015).

Berdasarkan data SUPAS 2005, kawasan Jabodetabek (Jakarta Bogor Depok Tangerang Bekasi) merupakan kawasan dengan mobilitas ulang-alik terbesar dibandingkan kawasan metropolitan lainnya di Indonesia dengan angka mobilitas ulang-alik keluar Jabodetabek mencapai 12,36 persen (Handiyatmo, 2009). Di Jabodetabek, pelaku mobilitas ulang-alik (komuter) telah meningkat sebesar 400 ribu orang dari tahun 2001 hingga 2014 (BPS, 2014). BPS mencatat pada tahun 2014, 81,3 persen komuter di Jabodetabek melakukan mobilitas ulang-alik dengan tujuan untuk bekerja. Semakin besarnya jumlah pekerja komuter di Jabodetabek menjadikan transportasi sebagai sarana penunjang yang sangat penting dalam menghubungkan permukiman di wilayah suburban dengan tempat bekerja.

Namun, tidak dapat dipungkiri bahwa Jabodetabek masih dihadapkan pada permasalahan transportasi. Pertumbuhan kendaraan bermotor (mobil penumpang dan sepeda motor) tetap tinggi seiring dengan meningkatnya mobilitas penduduk dan pertumbuhan ekonomi di Jabodetabek. Di sisi lain, sarana prasarana jaringan jalan raya yang ada tidak dapat berkembang secara cepat sehingga terjadi ketidakseimbangan antara jumlah kendaraan dengan ketersediaan jalan (Setyawan, 2012). Hal ini yang menyebabkan terjadinya kepadatan di jalan raya.

Berdasarkan hasil The Study on Integrated Transportation Master Plan for Jabodetabek (SITRAMP) oleh Badan Perencanaan Pembangunan Nasional (BAPPENAS) tahun 2004, kerugian akibat kemacetan mencapai 8,8 triliun rupiah yang mencakup pemborosan BBM, kerugian waktu yang terbuang, dan masalah kesehatan yang timbul akibat polusi udara. Penggunaan moda transportasi pribadi yang masih tinggi di kawasan Jabodetabek diperkirakan akan berdampak lebih besar jika terus berlanjut. Permasalahan yang timbul tidak hanya membawa dampak negatif pada penduduk yang melakukan komuter, namun juga pada lingkungan perkotaan secara keseluruhan.

Berkaitan dengan penelitian sebelumnya, Handiyatmo (2009) meneliti penggunaan jenis transportasi pelaku komuter di kawasan metropolitan salah satunya Jabodetabek dengan menggunakan data mentah Survei Penduduk Antar Sensus (SUPAS) 2005. Setyodhono (2017) juga meneliti terkait faktor pengaruh pekerja komuter Jabodetabek untuk menggunakan moda transportasi utama. Walaupun penelitian tersebut telah cukup menjelaskan secara komprehensif, namun keduanya baru menganalisis pada tingkat individu dan belum mempertimbangkan adanya faktor perbedaan karakteristik daerah asal pelaku komuter.

Data yang diperoleh melalui multistage sampling mengindikasikan unit observasi pada level terendah tidak sepenuhnya independen. Padahal asumsi independen ini 
dibutuhkan pada uji statistik. Jika asumsi ini tidak terpenuhi maka estimasi standard error dari uji statistiknya menjadi sangat kecil dan dapat menghasilkan signifikansi estimasi koefisien regresi yang keliru (Hox, 2010). Hal tersebut menjadi alasan model regresi satu level kurang tepat digunakan pada data berhierarki. Penelitian ini menganalisis data yang berstruktur hierarki yaitu pada data individu pekerja komuter dan karakteristik kabupaten/kota asalnya. Oleh karena itu, analisis multilevel dibutuhkan untuk mengetahui determinan yang memengaruhi pekerja komuter dalam memilih moda transportasi di Jabodetabek baik pada karakteristik individu maupun wilayah.

\section{Metodologi}

\subsection{Bahan dan Data}

Penelitian ini mencakup 13 kabupaten/kota di Jabodetabek yaitu Kota Jakarta Selatan, Kota Jakarta Pusat, Kota Jakarta Barat, Kota Jakarta Timur, Kota Jakarta Utara, Kabupaten Bogor, Kota Bogor, Kota Depok, Kabupaten Tangerang, Kota Tangerang, Kota Tangerang Selatan, Kabupaten Bekasi, dan Kota Bekasi. Penelitian ini mencakup individu yang bekerja dan menggunakan transportasi untuk melakukan mobilitas ulang-alik di Jabodetabek pada tahun 2014.

Tabel 1: Variabel-variabel bebas penelitian

\begin{tabular}{|c|c|c|}
\hline Variabel & Jenis Data & Keterangan \\
\hline Umur & Numerik & Tahun \\
\hline Jenis Kelamin & Kategorik & $\begin{array}{l}0: \text { Laki-laki * } \\
1: \text { Perempuan }\end{array}$ \\
\hline Status Kawin & Kategorik & $\begin{array}{l}0: \text { : Pernah kawin* } \\
1: \text { Belum pernah kawin }\end{array}$ \\
\hline Penghasilan & Kategorik & $\begin{array}{l}0:>\mathrm{UMK}^{*} \\
1: \leq \mathrm{UMK}^{\circ}\end{array}$ \\
\hline Kepemilikan Mobil & Kategorik & $\begin{array}{l}0 \text { : Punya Mobil } \\
1 \text { : Tidak Punya Mobil }\end{array}$ \\
\hline Kepemilikan Sepeda Motor & Kategorik & $\begin{array}{l}0: \text { : Punya Motor }^{\star} \\
1 \text { : Tidak Punya Motor }\end{array}$ \\
\hline Kepemilikan Sepeda & Kategorik & $\begin{array}{l}0 \text { : Punya Sepeda* } \\
1: \text { Tidak Punya Sepeda }\end{array}$ \\
\hline Jarak Tempuh & Kategorik & $\begin{array}{l}0: \text { Dekat }(\leq 30 \mathrm{~km})^{*} \\
1: \text { Jauh }(>30 \mathrm{~km})\end{array}$ \\
\hline Waktu Tempuh & Numerik & Menit \\
\hline Biaya Transportasi & Numerik & Ribu Rupiah \\
\hline Kepadatan penduduk & Numerik & Penduduk per km persegi \\
\hline
\end{tabular}

Keterangan: *) kategori referensi 
Data yang digunakan dalam penelitian ini bersumber dari data sekunder yaitu data mentah (raw data) Survei Komuter Jabodetabek 2014, publikasi Jakarta Dalam Angka 2015, Jawa Barat Dalam Angka 2015, dan Banten Dalam Angka 2015.

Penelitian ini menggunakan sebelas variabel bebas pada Tabel 1 dan satu variabel terikat yaitu moda transportasi oleh pekerja komuter terdiri dari transportasi pribadi, kereta, dan transportasi umum jalan raya. Berikut ini adalah variabel-variabel bebas yang digunakan, kategori dan referensinya.

\subsection{Metode Penelitian}

Penelitian ini menerapkan analisis deskriptif dan analisis inferensia melalui metode analisis regresi logistik multinomial multilevel dengan metode bayesian untuk estimasi parameternya. Pengolahan data dilakukan dengan program SPSS dan MLwiN. Model regresi logistik multinomial multilevel yang digunakan adalah model dengan random intercept yang mengasumsikan bahwa pengaruh setiap variabel bebas adalah sama pada setiap kabupaten/kota di level dua.

Analisis regresi logistik multinomial multilevel digunakan untuk mengetahui pengaruh variabel bebas pada level kabupaten/kota dan level individu terhadap pemilihan moda transportasi pekerja komuter. Analisis ini sesuai karena data yang digunakan merupakan data berstruktur hierarki dengan level 1 adalah individu dan level 2 adalah kabupaten/kota di Jabodetabek.

Snijders \& Bosker (1999) menjelaskan bentuk umum untuk model random intercept regresi multilevel dengan masing-masing satu variabel bebas di level individu dan grup adalah sebagai berikut:

$$
Y_{i j}=\beta_{0 j}+\beta_{j} x_{\mathrm{ij}}+R_{i j}
$$

Pada model di atas, notasi $j$ adalah jumlah kelompok di level dua $(j=1, \ldots, N)$ dan $i$ adalah index untuk individu dalam suatu kelompok $\left(i=1, \ldots, n_{j}\right)$. Selanjutnya, $Y_{i j}$ merupakan variabel terikat untuk unit ke-i pada level satu dalam kelompok ke-j pada level dua. $\beta_{0 j}$ ialah random intercept untuk kelompok ke-j pada level 2. $\beta_{j}$ adalah koefisien regresi untuk variabel bebas level individu. $x_{\mathrm{ij}}$ merupakan variabel bebas pada level individu. Variabel $R_{i j}$ merupakan error yang diasumsikan mutually independent dan berdistribusi $N\left(0, \sigma^{2}\right)$.

Kemudian, bentuk $\beta_{0 j}$ pada level grup dapat dipecah menjadi :

$$
\beta_{0 j}=\gamma_{00}+\gamma_{01} Z_{j}+U_{0 j}
$$

dengan, $\gamma_{0 o}$ adalah average intercept atau rata-rata intercept. $\gamma_{01}$ adalah koefisien regresi untuk variabel bebas level grup. $z_{1 j}$ merupakan variabel bebas pada level grup. Kemudian, error pada level grup ini yaitu $U_{0 j}$ diasumsikan random dan berdistribusi $N\left(0, \sigma_{0}^{2}\right)$. 
Melalui substitusi model (2) ke dalam model (1) dan dengan merubah indeks $\beta_{j}$ menjadi $\gamma_{10}$, maka terbentuk model random intercept regresi dua level dengan satu variabel bebas individu dan grup adalah sebagai berikut :

$$
Y_{i j}=\gamma_{o o}+\gamma_{10} x_{i j}+\gamma_{01} z_{j}+U_{0 j}+R_{i j}
$$

Jika pada model yang menggunakan lebih dari satu variabel bebas baik pada level individu maupun grup, maka model (3) dapat diubah menjadi berikut:

$$
Y_{i j}=\gamma_{o o}+\gamma_{10} x_{1 \mathrm{ij}}+\ldots+\gamma_{p o} x_{\mathrm{pij}}+\gamma_{01} z_{1 j}+\ldots+\gamma_{o q} z_{q j}+U_{0 j}+R_{i j}
$$

\section{Model Regresi Logistik Multilevel}

Saat variabel terikat berupa dikotomi maka model tersebut tidak berdistribusi normal, melainkan berdistribusi keluarga eksponensial yaitu binomial. Variabel yang tidak berdistribusi normal dapat diselesaikan melalui pendekatan generalized linier model dengan melakukan transformasi (Hox, 2010). Link function untuk data binomial dan proporsi adalah fungsi logit yaitu $\operatorname{logit}(x)=\ln [x /(1-x)]$.

Transformasi logit yang digunakan untuk model dengan beberapa variabel bebas adalah sebagai berikut

$$
\operatorname{logit}\left(\pi_{i j}\right)=\ln \left[\frac{\pi_{i j}}{1-\pi_{i j}}\right]=\beta_{0 j}+\beta_{1} x_{1 \mathrm{ij}}+\ldots .+\beta_{p} x_{\mathrm{pij}}
$$

Koefisien regresi $\beta$ akan bervariasi pada level grup dan dapat diubah menjadi:

$$
\begin{aligned}
& \beta_{0 j}=\gamma_{o o}+\gamma_{01} z_{j}+\ldots+\gamma_{0 q} z_{q j}+U_{0 j} \\
& \beta_{1}=\gamma_{10} \text { hingga } \beta_{p}=\gamma_{p o} \text { sesuai jumlah variabel bebas pada level satu }
\end{aligned}
$$

Melalui substitusi persamaan (6) dan (7) ke persamaan (5) maka diperoleh model regresi logistik dua level dengan random intercept sebagai berikut :

$$
\operatorname{logit}\left(\pi_{i j}\right)=\ln \left[\frac{\pi_{i j}}{1-\pi_{i j}}\right]=\gamma_{o 0}+\gamma_{10} x_{1 \mathrm{ij}}+\ldots+\gamma_{p 0} x_{\mathrm{pij}}+\gamma_{01} z_{1 j}+\ldots+\gamma_{0 q} z_{q j}+U_{0 j}
$$

Selanjutnya, regresi logistik multinomial multilevel merupakan bentuk modifikasi dari regresi logistik biner multilevel untuk menganalisis kasus yang memiliki outcome variable (variabel terikat) berbentuk skala nominal dengan kategori lebih dari dua. Diasumsikan terdapat tiga kategori pada variabel terikat, $Y$ yang diberi kode 0,1 dan 2. Pada model regresi logistik multinomial, variabel terikat dengan tiga kategori akan membentuk dua fungsi logit (Hosmer et al., 2013). Dalam pembentukan kedua fungsi tersebut, perlu ditentukan kategori yang akan menjadi nilai referensi contohnya $Y=0$ dan kategori sukses $Y=t$ sehingga fungsi logit multilevel yang terbentuk adalah sebagai berikut. 
1. Model fungsi logit dengan $Y=1$ terhadap fungsi logit $Y=0$

$$
\operatorname{logit}\left(\pi_{i j}\right)_{1}=\ln \left[\frac{\left(\pi_{i j}\right)_{1}}{1-\left(\pi_{i j}\right)_{1}}\right]=\gamma_{100}+\gamma_{110} x_{1 \mathrm{ij}}+\ldots+\gamma_{1 p 0} x_{\mathrm{pij}}+\gamma_{101} Z_{1 j}+\ldots+\gamma_{10 q} Z_{q j}+U_{10 j}
$$

2. Model fungsi logit dengan $Y=2$ terhadap fungsi logit $Y=0$

$$
\operatorname{logit}\left(\pi_{i j}\right)_{2}=\ln \left[\frac{\left(\pi_{i j}\right)_{2}}{1-\left(\pi_{i j}\right)_{2}}\right]=\gamma_{200}+\gamma_{210} x_{1 \mathrm{ij}}+\ldots+\gamma_{2 p 0} x_{\mathrm{pij}}+\gamma_{201} Z_{1 j}+\ldots+\gamma_{20 q} Z_{q j}+U_{20 j}
$$

Tahapan analisis regresi logistik multinomial multilevel adalah sebagai berikut:

\section{a. Estimasi Parameter}

Estimasi parameter pada model regresi logistik pada umumnya dilakukan dengan menggunakan metode Maximum Likelihood (ML). Penggunaan metode ML pada analisis multilevel harus memenuhi asumsi bahwa sampel yang digunakan harus cukup besar (> 50 sampel). Sampel yang kecil pada level dua dapat menyebabkan estimasi parameter yang bias. Penambahan jumlah sampel pada level dua merupakan hal yang sulit untuk dilakukan karena dua alasan yaitu biaya dan batasan cakupan suatu survei yang telah dilaksanakan (Maas \& Hox, 2005).

Dalam mengatasi hal tersebut, estimasi parameter pada analisis multilevel dapat menggunakan metode bayesian karena metode ini dapat berjalan dengan baik pada ukuran sampel yang lebih kecil.

\section{b. Pemilihan Model}

Spiegehalter et al. (2002) menggunakan nilai deviance pada Markov Chain Monte Carlo (MCMC) untuk melakukan pemilihan model terbaik yang dikenal dengan Deviance Information Criterion (DIC).

$$
\mathrm{DIC}=\overline{\mathrm{D}}+\mathrm{PD}
$$

DIC dihitung dari nilai rata-rata deviance yang dihasilkan dari setiap iterasi pada MCMC $(\bar{D})$ dan jumlah parameter yang efektif dalam model yg dijalankan (PD) (Browne, 2016). Model yang terbaik merupakan model dengan nilai DIC terkecil.

\section{c. Pengujian Parameter Secara Parsial}

Pengujian parameter dari koefisien regresi secara parsial dapat menggunakan uji Wald (Hosmer et al., 2013). Uji parsial digunakan untuk menentukan variabel bebas mana saja yang memiliki pengaruh terhadap variabel terikat.

\section{d. Interpretasi Parameter}

Interpretasi pada persamaan regresi logistik multinomial multilevel sama seperti regresi logistik multinomial satu level yaitu dapat melalui tanda koefisien regresi, nilai odds ratio atau probabilita. Dalam penelitian ini, tanda koefisien regresi dan odds ratio digunakan untuk mengetahui arah hubungan dan seberapa besar kecenderungan setiap variabel bebas terhadap pemilihan moda transportasi.

\section{e. Penghitungan Intraclass Correlation}

Nilai intraclass correlation (ICC) menunjukkan tingkat kemiripan karakteristik antar unit mikro (individu) dalam unit makro (kelompok) yang sama (Snijders \& Bosker, 
1999). Nilai ICC dapat diperoleh dari hasil estimasi variansi pada null model / model yang tidak mengandung variabel bebas. Nilai ICC dapat dihitung melalui:

$$
I C C=\frac{\sigma_{0}^{2}}{\sigma_{0}^{2}+\sigma^{2}}=\frac{\sigma_{0}^{2}}{\sigma_{0}^{2}+\frac{\pi}{3}}
$$

dengan $\sigma_{0}^{2}$ adalah variansi antar kelompok pada level dua dan $\sigma^{2}$ adalah variansi antar individu pada level satu. Pada distribusi logistik standar, nilai variansi antar individu pada level satu adalah $\frac{\pi}{3}$ (Hox, 2010). Nilai ICC yang terbentuk pada regresi logistik multinomial multilevel akan sesuai dengan jumlah model yang terbentuk.

Dalam penelitian ini, Intraclass correlation (ICC) digunakan untuk melihat seberapa besar keragaman/variansi pemilihan moda transportasi pekerja komuter di jabodetabek yang dapat dijelaskan oleh adanya perbedaan karakteristik antar kabupaten/kota.

\section{Hasil dan Pembahasan}

Hasil pengolahan Survei Komuter Jabodetabek 2014 pada Gambar 1 menunjukkan bahwa secara keseluruhan terdapat 73 persen pekerja komuter yang memilih menggunakan moda transportasi pribadi, 19 persen menggunakan transportasi umum jalan raya, dan sisanya 8 persen memilih menggunakan kereta. Hasil ini menunjukkan terjadinya kenaikan persentase penggunaan moda transportasi pribadi yang tinggi jika dibandingkan dengan tahun 2005 yang pada saat itu masih didominasi transportasi umum. Handiyatmo (2009) dengan menggunakan data SUPAS 2005 menemukan bahwa penggunaan transportasi pribadi saat itu sebesar 39,3 persen yang artinya jauh lebih rendah dibandingkan keadaan tahun 2014. Peningkatan penggunaan transportasi pribadi ini menunjukkan peningkatan kemampuan ekonomi masyarakat yang berdampak pada peningkatan daya beli kendaraan bermotor. Penggunaan transportasi pribadi oleh komuter seakan menegaskan bahwa kenyamanan, keamanan, dan keandalan dapat dipenuhi oleh transportasi pribadi (BPS, 2009).

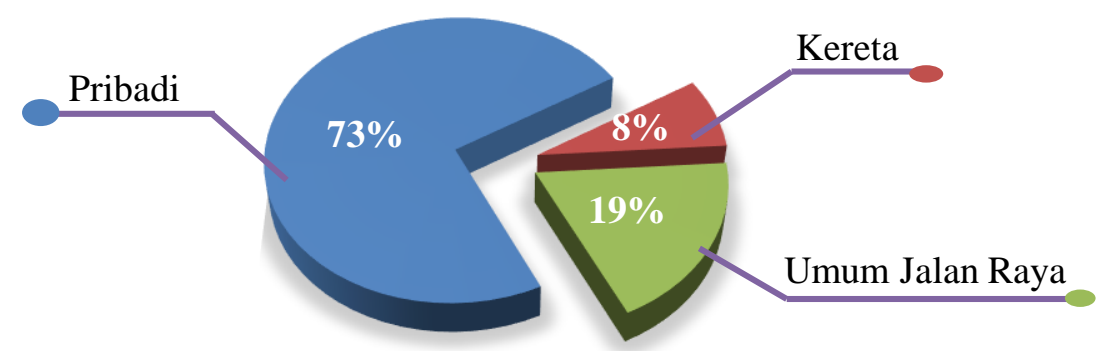

Gambar 1: Persentase pekerja komuter menurut preferensi moda transportasi.

Selanjutnya Gambar 2 memperlihatkan persentase penggunaan transportasi pribadi secara lebih rinci menurut kabupaten/kota asal pekerja komuter. Penggunaan transportasi pribadi yang tinggi terjadi pada kota Jakarta Barat, Kota Tangerang Selatan, Kabupaten Tangerang, dan Kabupaten Bekasi. Tingginya penggunaan 
transportasi pribadi di Jakarta Barat terkait dengan belum optimalnya penggunaan jalur kereta yang menuju Jakarta Pusat dan jumlah stasiun kereta di Jakarta Utara yang masih sedikit dengan jarak antar stasiun yang cukup jauh, padahal kedua wilayah tersebut menjadi tujuan utama pekerja komuter dari Jakarta Barat.

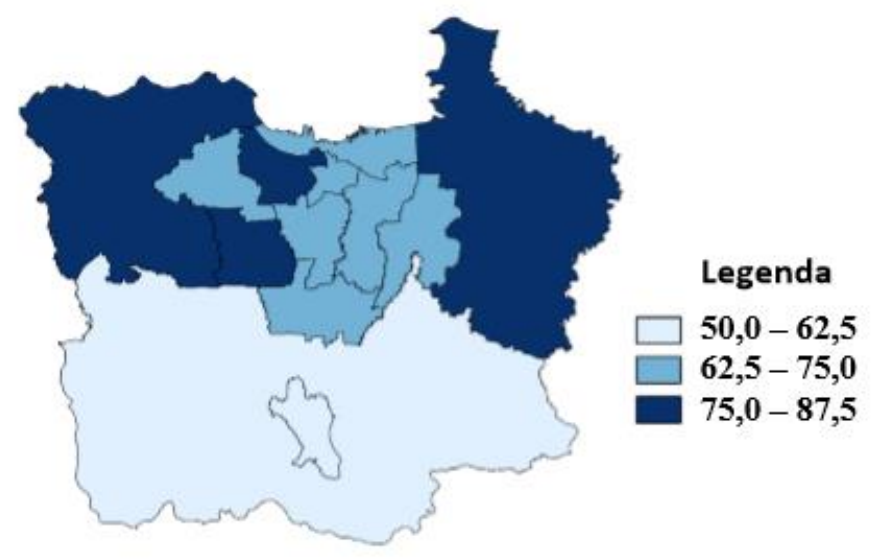

Gambar 2: Persentase pekerja komuter yang menggunakan transportasi pribadi menurut kabupaten/kota di Jabodetabek.

Belum tersedianya jalur kereta commuter line pada saat itu juga menjadi penyebab tingginya persentase penggunaan transportasi pribadi di Kabupaten Bekasi dan Kabupaten Tangerang. Selanjutnya, penggunaan transportasi pribadi di Tangerang Selatan ternyata tetap tinggi walaupun telah memiliki jalur kereta commuter line. Hal ini kemungkinan disebabkan karena sebagian besar pekerja komuter dari Tangerang Selatan bekerja di Jakarta Selatan yang kemudian terkait dengan tidak tersedianya jalur kereta langsung menuju daerah Jakarta Selatan sehingga memerlukan transit terlebih dahulu di Stasiun Tanah Abang.

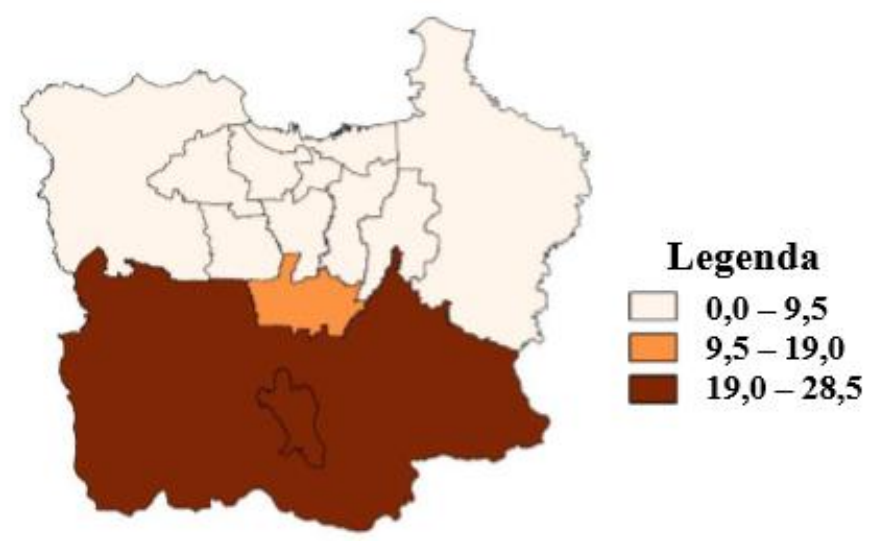

Gambar 3: Persentase pekerja komuter yang menggunakan transportasi kereta menurut kabupaten/kota di Jabodetabek.

Gambar 3 menunjukkan bahwa Kota Bogor dan Kabupaten Bogor memiliki persentase penggunaan kereta yang paling besar dibandingkan kota / kabupaten lainnya. Jarak Kota Bogor dan Kabupaten Bogor yang relatif jauh dengan Jakarta 
sebagai wilayah tujuan pekerja komuter diduga memengaruhi pilihan moda transportasi pekerja komuter untuk memilih kereta dibandingkan transportasi pribadi. Jarak yang jauh akan menyebabkan kelelahan jika komuter menggunakan transportasi pribadi (BPS, 2009). Dengan kata lain dapat dikatakan bahwa pekerja komuter yang berasal dari Kota Bogor dan Kabupaten Bogor sangat bergantung pada ketersediaan transportasi umum khususnya kereta.

Gambar 4 menunjukkan penggunaan transportasi umum jalan raya tertinggi terjadi di wilayah Jakarta Pusat dan Jakarta Utara dengan persentase sebesar 30,4 persen dan 26,7 persen. Selain karena masih kurangnya aksesibilitas kereta khususnya di Jakarta Utara, hal ini kemungkinan juga disebabkan karena pada kedua wilayah tersebut telah tersedia berbagai koridor/jalur Transjakarta sehingga pekerja komuter yang berasal dari Jakarta Pusat dan Jakarta Utara dapat dengan mudah menjangkau berbagai tempat di luar kedua wilayah tersebut.

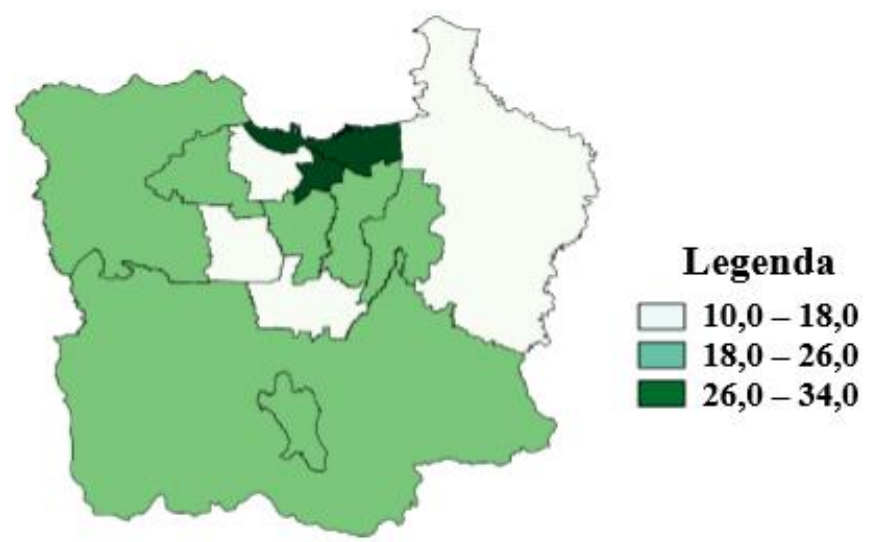

Gambar 4: Persentase pekerja komuter yang menggunakan transportasi umum jalan raya menurut kabupaten/kota di Jabodetabek.

Berkaitan dengan analisis pengaruh variabel bebas terhadap variabel terikat, model multinomial multilevel yang dibentuk adalah sebagai berikut:

1. Pemilihan moda transportasi antara kereta dengan transportasi pribadi

$$
\begin{aligned}
\operatorname{logit}\left(\pi_{i j}\right)_{1}= & \mathrm{V}_{100}+\mathrm{V}_{110} \text { Umur }_{\mathrm{ij}}+\mathrm{V}_{120} \text { JenisKelamin }_{\mathrm{ij}}+\mathrm{V}_{130} \text { StatusKawin }_{\mathrm{ij}}+ \\
& \mathrm{V}_{140} \text { Penghasilan }_{\mathrm{ij}}+\mathrm{V}_{150} \text { Mobil }_{\mathrm{ij}}+\mathrm{Y}_{160} \text { Motor }_{\mathrm{ij}}+\mathrm{V}_{170} \text { Sepeda }_{\mathrm{ij}}+ \\
& \mathrm{V}_{180} \text { JarakTempuh }_{\mathrm{ij}}+\mathrm{V}_{190} \text { WaktuTempuh }_{\mathrm{ij}}+\mathrm{V}_{1100} \text { Biaya }_{\mathrm{ij}}+ \\
& \mathrm{V}_{101} \text { KepadatanPenduduk }_{\mathrm{j}}+\mu_{10 \mathrm{j}}
\end{aligned}
$$

2. Pemilihan moda transportasi antara transportasi umum jalan raya dengan transportasi pribadi

$$
\begin{aligned}
\operatorname{logit}\left(\pi_{i j}\right)_{2}= & \mathrm{V}_{200}+\mathrm{V}_{210} \text { Umur }_{\mathrm{ij}}+\mathrm{V}_{220} \text { JenisKelamin }_{\mathrm{ij}}+\mathrm{V}_{230} \text { StatusKawin }_{\mathrm{ij}}+ \\
& \mathrm{V}_{240} \text { Penghasilan }_{\mathrm{ij}}+\mathrm{V}_{250} \text { Mobil }_{\mathrm{ij}}+\mathrm{V}_{260} \text { Motor }_{\mathrm{ij}}+\mathrm{V}_{270} \text { Sepeda }_{\mathrm{ij}}+ \\
& \mathrm{V}_{280} \text { JarakTempuh }_{\mathrm{ij}}+\mathrm{V}_{290} \text { WaktuTempuh }_{\mathrm{ij}}+\mathrm{V}_{2100} \text { Biaya }_{\mathrm{ij}}+ \\
& \mathrm{V}_{201} \text { KepadatanPenduduk }_{\mathrm{j}}+\mu_{20 \mathrm{j}}
\end{aligned}
$$

Pemilihan model awalnya dilakukan dengan memeriksa random effect melalui perbandingan nilai Deviance Information Criterion (DIC) antara model regresi logistik multinomial satu level dengan model regresi logistik multinomial multilevel pada kondisi 
tidak mengandung variabel bebas (null mode). Berdasarkan output MLwiN diperoleh bahwa pada kondisi null model, nilai DIC untuk model regresi logistik multinomial multilevel lebih kecil dibandingkan satu level. Dengan demikian, dapat disimpulkan bahwa model regresi logistik multinomial multilevel yang mengandung random effect lebih baik untuk digunakan dibandingkan dengan model regresi logistik multinomial satu level.

Selanjutnya dilakukan perbandingan model multilevel antara null model dengan conditional model. Berdasarkan output MLwiN, diperoleh bahwa nilai DIC untuk model multilevel yang mengandung seluruh variabel bebas (conditional model) lebih kecil dibandingkan model multilevel yang tidak mengandung variabel bebas (null mode). Dengan demikian dapat disimpulkan bahwa model multilevel yang mengandung seluruh variabel bebas lebih baik dibandingkan model multilevel yang tidak mengandung variabel bebas.

\begin{tabular}{lr} 
Tabel 2: Hasil Estimasi DIC dan ICC \\
\hline DIC $_{\text {satu level(null) }}$ & 6963,47 \\
DIC $_{\text {multilivel(null) }}$ & 6640,28 \\
DIC Cultilievel(conditiona) & 5275,45 \\
ICC & 31,21 \\
IC $C_{\text {kereta }}(\%)$ & 4,30 \\
\hline
\end{tabular}

Estimasi parameter conditional model dengan metode bayesian menghasilkan persamaan regresi logistik multinomial multilevel dengan random intercept untuk pemilihan moda transportasi pekerja komuter sebagai berikut.

1. Persamaan pemilihan moda antara kereta dengan transportasi pribadi.

$$
\begin{aligned}
& \operatorname{logit}\left(\pi_{i j}\right)_{1}=-5,146+0,031 \text { Umur }_{\mathrm{ij}}+1,562 \text { JenisKelamin }_{\mathrm{ij}}+ \\
& 0,671 \text { StatusKawin }_{i j}-0,183 \text { Penghasilan }_{i j}-0,207 \text { Mobi }_{i j}+ \\
& \text { 1,607 } \text { Motor }_{\mathrm{ij}}+0,147 \text { Sepeda }_{\mathrm{ij}}+1,304 \mathrm{JarakTempuh}_{\mathrm{ij}}+
\end{aligned}
$$

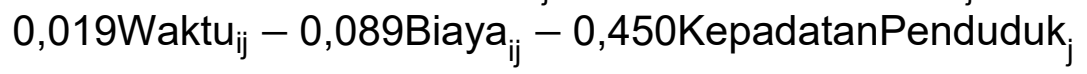

2. Persamaan pemilihan moda antara transportasi umum jalan raya dengan transportasi pribadi.

$$
\begin{aligned}
& \operatorname{logit}\left(\pi_{i j}\right)_{2}=-5,271+0,036 \text { Umur }_{i j}+2,091 \text { JenisKelamin }_{i j}+
\end{aligned}
$$

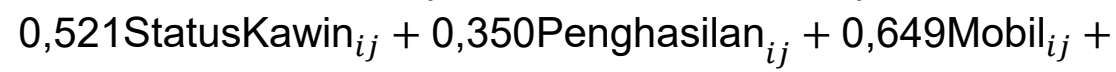

$$
\begin{aligned}
& \text { 1,910 } \text { Motor }_{i j}+0,198 \text { Sepeda }_{i j}+0,144 \text { JarakTempuh }_{i j}+ \\
& \text { 0,016 } \text { Waktu }_{i j}-0,025 \text { Biaya }_{i j}+0,059 \text { KepadatanPenduduk }_{j}
\end{aligned}
$$

Kemudian, uji signifikansi parameter secara parsial dilakukan melalui uji Wald sehingga dapat ditentukan variabel bebas mana saja yang memengaruhi pemilihan moda transportasi pekerja komuter. Berikut adalah hasil pengujian variabel bebas dalam model regresi logistik multinomial multilevel. 
Tabel 3: Hasil Estimasi Parameter, Uji Wald, dan Nilai Odds Ratio

\begin{tabular}{lrrrrrr}
\hline \multirow{2}{*}{ Variabel } & \multicolumn{5}{c}{ Koda Transportasi } \\
\cline { 2 - 7 } & \multicolumn{1}{c}{$\widehat{c} \boldsymbol{\gamma}$} & \multicolumn{1}{c}{ Wald } & $\operatorname{Exp}(\widehat{\gamma})$ & \multicolumn{1}{c}{$\widehat{\gamma}$} & \multicolumn{1}{c}{ Wald } & Exp $(\widehat{\gamma})$ \\
\hline Constant & $-5,146$ & $-10,50$ & & $-5,271$ & 16,840 \\
Umur & 0,031 & 4,430 & 1,031 & 0,036 & 7,200 & 1,037 \\
Jenis Kelamin & 1,562 & 10,920 & 4,768 & 2,091 & 21,780 & 8,093 \\
Status Kawin & 0,671 & 3,791 & 1,956 & 0,521 & 4,378 & 1,684 \\
Penghasilan & $-0,183$ & 1,173 & 0,833 & 0,350 & 3,535 & 1,419 \\
Kepemilikan Mobil & $-0,207$ & $-1,380$ & 0,813 & 0,649 & 5,547 & 1,914 \\
Kepemilikan Motor & 1,607 & 7,616 & 4,988 & 1,910 & 13,940 & 6,753 \\
Kepemilikan Sepeda & 0,147 & 1,088 & 1,158 & 0,198 & 2,175 & 1,219 \\
Jarak Tempuh & 1,304 & 8,306 & 3,684 & 0,144 & 1,125 & 1,155 \\
Waktu Tempuh & 0,019 & 9,500 & 1,019 & 0,016 & 16,000 & 1,016 \\
Biaya & $-0,089$ & 11,120 & 0,915 & $-0,025$ & $-6,250$ & 0,975 \\
Kepadatan Penduduk & $-0,450$ & $-1,428$ & 0,638 & 0,059 & 0,464 & 1,061 \\
\hline
\end{tabular}

Keputusan tolak $\mathrm{H}_{0}$ jika nilai Wald lebih dari $Z_{0,05}=1,645$ sehingga disimpulkan bahwa variabel bebas yang diuji berpengaruh positif secara signifikan terhadap pemilihan moda transportasi pekerja komuter. Selain itu, keputusan tolak $\mathrm{H}_{0}$ jika nilai Wald kurang dari $Z_{-0,05}=-1,645$ sehingga disimpulkan bahwa variabel bebas yang diuji berpengaruh negatif secara signifikan terhadap pemilihan moda transportasi pekerja komuter.

Dengan demikian, dapat dilihat bahwa pemilihan moda antara kereta dan transportasi pribadi secara signifikan dipengaruhi oleh umur, jenis kelamin, status kawin, kepemilikan mobil dan motor, jarak dan waktu tempuh, serta biaya. Selanjutnya pemilihan moda antara transportasi umum jalan raya dan transportasi pribadi secara signifikan dipengaruhi oleh umur, jenis kelamin, status kawin, kepemilikan mobil, motor dan sepeda, waktu tempuh dan biaya.

Variabel sosio-demografi dari pekerja komuter terlihat cukup memengaruhi pada pemilihan moda transportasi. Seiring dengan bertambahnya usia, pekerja komuter akan semakin cenderung memilih transportasi umum baik kereta maupun jalan raya dibandingkan transportasi pribadi. Selanjutnya dapat dikatakan juga bahwa perempuan cenderung untuk memilih transportasi umum kereta ataupun jalan raya dibandingkan pekerja komuter laki-laki. Hal ini kemungkinan berkaitan dengan keahlian berkendara dan keberanian di jalan raya.

Kemudian dari sisi status perkawinan, pekerja komuter yang belum kawin memiliki kecenderungan hampir dua kali lebih besar untuk menggunakan kereta. Hal ini serupa juga terjadi dalam pemilihan transportasi umum jalan raya dengan pekerja komuter yang belum kawin memiliki kecenderungan lebih besar untuk menggunakannya dibandingkan yang telah kawin.

Penghasilan pekerja komuter menunjukkan pengaruh yang signifikan terhadap pemilihan moda transportasi umum jalan raya. Pekerja komuter dengan penghasilan maksimal setara UMK memiliki kecenderungan hampir dua kali lebih besar untuk memilih transportasi umum jalan raya dibandingkan dengan yang memiliki penhasilan di atas UMK. Pekerja komuter dengan penghasilan yang lebih tinggi memiliki pilihan untuk menentukan moda transportasinya. Dengan realitas bahwa saat ini transportasi umum jalan raya belum mampu memenuhi kenyamanan maupun keamanan, wajar 
jika pekerja komuter yang memiliki penghasilan lebih tinggi akan lebih memilih transportasi pribadi.

Selanjutnya, kepemilikan transportasi pribadi seperti mobil, sepeda motor, dan sepeda memiliki pengaruh yang signifikan. Pekerja komuter yang tidak memiliki sepeda motor akan cenderung memilih transportasi umum dengan kecenderungan masing-masing hampir lima kali lipat dan tujuh kali lipat untuk memilih kereta dan transportasi umum jalan raya. Pekerja komuter yang tidak memiliki mobil cenderung memilih transportasi umum jalan raya sebesar hampir dua kali lipatnya dibandingkan yang memiliki mobil. Ini jelas memperlihatkan bahwa pekerja komuter yang memiliki mobil belum tertarik untuk menggunakan transportasi umum jalan raya dengan pertimbangan tingkat kenyamanan yang belum setara.

Jarak yang ditempuh oleh pekerja komuter memberikan pengaruh cukup signifikan pada pemilihan kereta. Pekerja komuter yang menempuh jarak jauh memiliki kecenderungan sebesar 3,6 kali lebih besar untuk memilih menggunakan kereta. Jarak yang jauh akan menyebabkan kelelahan bagi pekerja komuter sehingga para pekerja komuter yang berasal dari Bogor lebih bergantung pada kereta. Selain itu, semakin lama waktu yang ditempuh akan meningkatkan kecenderungan untuk menggunakan transportasi umum baik kereta maupun transportasi umum jalan raya.

Kemudian, dari biaya transportasi terlihat bahwa setiap bertambahnya Rp 1.000 biaya transportasi yang dikeluarkan oleh pekerja komuter, maka akan mengurangi kecenderungan menggunakan kereta sebesar 8,5 persen dan sebesar 2,5 persen untuk menggunakan transportasi umum jalan raya dibandingkan transportasi pribadi. Ini menjadi sinyal bahwa biaya/ongkos transportasi umum harus dijaga tetap terjangkau oleh pekerja komuter.

Terakhir, analisis multilevel memungkinkan untuk menganalisis efek dari adanya perbedaan karakteristik kabupaten/kota asal pekerja komuter. Intraclass correlation (ICC) digunakan untuk melihat seberapa besar keragaman yang dijelaskan oleh adanya perbedaan karakteristik antar kabupaten/kota. Hasil ICC untuk kereta menunjukkan hasil yang cukup besar yaitu 31,2 persen. Sedangkan ICC untuk transportasi umum jalan raya menghasilkan angka yang relatif kecil yaitu sebesar 4,3 persen. ICC yang bernilai kecil mengindikasikan faktor individu dapat lebih menjelaskan keragaman dalam model (Gonzalez et al., 2013). Pada transportasi kereta, perbedaan antar kabupaten/kota terlihat cukup berkontribusi pada keragaman pemilihan kereta. Hasil ini memperlihatkan bahwa ada kemungkinan karakteristik wilayah lainnya yang belum tercakup seperti tingkat ketersediaan sarana transportasi umum berperan penting untuk menjelaskan keragaman pemilihan kereta.

\section{Simpulan}

Berdasarkan hasil penelitian diatas dapat dirumuskan kesimpulan bahwa penggunaan penggunaan moda transportasi oleh pekerja komuter di Jabodetabek pada tahun 2014 lebih didominasi oleh transportasi pribadi dibandingkan transportasi umum jalan raya dan kereta.

Penggunaan kereta oleh pekerja komuter dipengaruhi oleh variabel umur, jenis kelamin, status perkawinan, kepemilikan motor, jarak tempuh, waktu tempuh, dan biaya. Sedangkan untuk penggunaan transportasi umum jalan raya oleh pekerja 
komuter dipengaruhi oleh umur, jenis kelamin, status perkawinan, penghasilan kepemilikan moda transportasi pribadi (mobil, motor dan sepeda), waktu tempuh, dan biaya. Variabel kepadatan penduduk ternyata tidak memengaruhi pemilihan moda transportasi baik pada kereta maupun transportasi umum jalan raya.

\section{Daftar Pustaka}

Ariana, I. (2004). Karakteristik Wilayah dan Pola Persebaran Penduduk Komuter DKI Jakarta [Tesis]. Depok: Universitas Indonesia.

Badan Perencanaan Pembangunan Nasional. (2004). SITRAMP: The Study on Integrated Transportation Master Plan for Jabodetabek. Jakarta: BAPPENAS.

Badan Pusat Statistik. (2009). Profil Komuter Hasil SUPAS 2005. Jakarta: BPS.

Badan Pusat Statistik. (2014). Statistik Komuter Jabodetabek. Jakarta: BPS

Badan Pusat Statistik. (2015). Statistik Mobilitas Penduduk dan Tenaga Kerja 2015. Jakarta: BPS.

Browne, W. J. (2016). MCMC Estimation in MLwiN. Bristol: University of Bristol.

Gonzales, P., Banos, J.F., Mayor, M., \& Suarez, P. (2013). Determinants of Ground Transport Modal Choice in Long-Distance in Spain. Gijon, Spanyol.

Handiyatmo, D. (2009). Penggunaan Jenis Transportasi oleh Pelaku Mobilitas Ulang Alik di Enam Kawasan Metropolitan (Analisis Data SUPAS 2005) [Tesis]. Depok: Universitas Indonesia.

Hosmer, D., Lemeshow, S., \& Sturdivant, R.X. (2013). Applied Logistic Regression $3^{\text {rd }}$ Edition. New Jersey: John Wiley \& Sons, Inc.

Hox, J. J. (2010). Multilevel Analysis: Techniques and Applications ( $2^{\text {nd }}$ ed). New York: Routledge

Maas, C.J.M., \& Hox, J. J. (2005). Sufficient Sample Sizes for Multilevel Modeling. Utrecht: Hogrefe \& Huber.

Setyawan, H. (2012). Kualitas Pelayanan Transportasi (Studi Kasus Transjakarta Busway di Provinsi Daerah Khusus Ibukota Jakarta) [Tesis]. Depok: Universitas Indonesia.

Setyodhono, S. (2017). Faktor yang Mempengaruhi Pekerja Komuter di Jabodetabek Menggunakan Moda Transportasi Utama. Warta Penelitian Perhubungan, Volume 29, Nomor 1.

Snijders, T., \& Bosker, R. (1999). Multilevel Analysis: An Introduction to Basic and Advanced Multilevel Modeling. London: Sage.

Spiegehalter, D. J., Best, N. G., Carlin, B. P., \& Linde, A. v. (2002). Bayesian Measures of Model Complexity and Fit. Cambridge, UK: Royal Statistical Society. 